\title{
WHAT DO COLOUR NAMES TELL US? THE CASE OF KAZAKH
}

\author{
BENCE GREZSA \\ Department of Altaic Studies, University of Szeged \\ Egyetem u. 2. Szeged 6722, Hungary \\ e-mail: grezsb@gmail.com
}

The linguistic research of colour names is a popular topic. It contributes to a better understanding of the history and development of languages and the culture of native speakers. This study deals with Kazakh colour names from the aspect of historical linguistics. First, the paper introduces the symbolic interpretation of Kazakh colours, then the categories and the functions of words derived from colour names are dealt with. Compounds that contain colour names are also in the focus of the present research. In the case of compounds, a specific usage of the colour names forming a particular meaning comes into view, which is a very interesting semantic field in Kazakh.

Key words: colour names, basic colour names, symbolism, additional meaning, derivation, suffixes, compounds.

\section{Introduction}

The present study deals with the colour names of the Kazakh language from the aspect of semantics and word formation. This topic is a very popular field of linguistic studies, since the research of colour names yields much information about the cultural, social and historical background of a community. In the case of Kazakh, the investigation of the colour names could bring to surface interesting facts regarding language contacts and typological features. Although a number of studies have been written on the subject of colour names in the Turkic languages, no work providing a detailed study of the colour names in Kazakh exists. Colour names could be classified on the strength of several viewpoints. During the demonstration of the colour system of the Kazakh language, I mainly focused on the cultural and semantic characteristics. The data were collected from different Kazakh dictionaries (Bektaev 1999; 
Kenesbaev 1977; Koç 2003) and grammars (Balakaev-Baskakov-Kenesbaev 1962; Žanpejisov-Žusajin et al. 2002). My sources contain approximately 500 items.

\section{Research on Colour Names}

The research of colour names is a widely investigated topic of lingustics. Here only those theories will be reviewed and summarised which are relevant with respect to the Kazakh colour names. In doing so, it becomes obvious that each theory basically follows either the relativist or the universalist appoach. The relativist theory (or known as the Sapir-Whorf hypotesis) focuses on the specific semantic fields of different languages. The purpose of this research is to compare and demonstrate these specific characteristics of every single language. This theory is based on the assumption that each language has its own special system for the colour names (Sipöcz 1994, pp. 10-11). However, the principle of the universalist theory is the opposite. This conception was created by Berlin and Kay (also known as the Berlin-Kay theory), who have had the view that the formation of the colour names is universal in every language, since the colour perception is an innate, psychological process. In order to prove their argument, they have studied colour names in twenty different languages from various languages families. Therefore, they have created the term 'basic colour names' and have established a progressive pattern with seven stages on the score of the basic colour names. They consider a colour name as basic only when its usage is not limited to an external characteristic of an animal or an object, it cannot be separated into other elements and was not borrowed from another language. Furthermore, a basic colour name must not denote the tone of another colour and its application must be definite and frequent for the native speakers. The univesalist theory can be adapted to Kazakh as well (Berlin-Kay 1968, pp. 1-23)

With regard to Turkology, researchers engage in colour names from linguistic, cultural and historical points of view. From the side of linguisticts, the work by LaudeCirtatuas (1961) has to be mentioned who has collected the different colour names from different Turkic languages and has also included several Kazakh items. Another important study was written by Stachowski (2010) about the colours in Yakut. He deals with Yakut colour names mainly from the semantic aspect and gives some comments regarding their etymology. Taking into account the Turkic colour names from the aspect of symbolism, Küçük (2010) examines the cultural signification of colour names among historical Turkic peoples in his article. In the discipline of colour symbolism, few works can be found about the Kazakh language. For instance, the phraseological dictionary of Kazakh language published by Kenesbaev (1977) gives much information about the symbolic interpretation of colour names. Kadaşeva (1996) analyses the symbolic usage of colour names interpreting their basic meaning. 


\section{Colour Names in Kazakh}

For a suitable classification of the Kazakh colour names, word-formation could be a very useful instrument. In this regard, the colour names are divided into three different groups:

basic colour names;

colour names formed by suffixes;

compounds which consist of at least one colour name.

Applying the criteria of the universalist theory to the Kazakh language, nine colours can be regarded as a basic term:

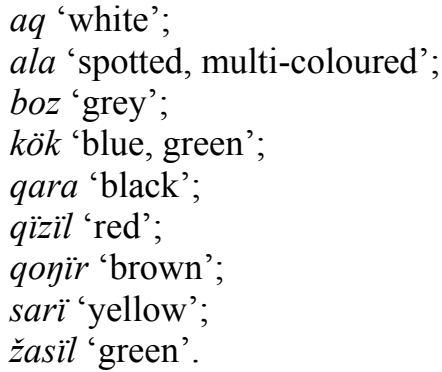

Although the universalists do not take notice of the etymology, to my mind it is a very important part in the case of Kazakh colour names. Taking a stock of the original usage of colours in Old Turkic, it turns out that some of them were originally applied only to the fur or hair colour of animals:

$a q$ 'white' $\sim$ Old Turkic $\bar{a} q$ 'white coat of an animal' (Clauson 1972, pp. 75);

boz 'grey' Old Turkic boz 'grey coat of an animal' (Clauson 1972, pp. 388389);

qoyïr 'brown' Old Turkic qoyur 'brown hair of an animal' (Clauson 1972, pp. 639).

Moreover, according to Clauson's argument (1972, pp. 681, 683-684), the colour name qïzil 'red' is a derived form from the word qüz- 'to be red with anger, shame' added the deverbal nomen suffix $-X l$. Clauson's argument is partially accepted ${ }^{1}$ by Erdal (1991, pp. 99-100) as well.

Likewise, $y \bar{a} s \grave{i l}$ 'green, colour of the fresh vegetation' (which is represented as $\check{z}$ asïl in Kazakh) can be segmented into the adjective $y \bar{a} \check{s}$ 'fresh, moist' and the denominal adjective suffix $+s X l$ (Clauson 1972, pp. 975, 978). Besides, the Old Turkic item $k \overline{o ̈ k}$ (Kazakh kök) originally had the meaning 'sky' (Clauson 1972, pp. 708-709).

So if the etymology is taken into consideration as a criterium as well, only three of the colour names can be taken as basic:

ala 'parti-coloured, dappled, mottled', cf. Old Turkic àla 'dappled, mottled'; qara 'black', cf. Old Turkic qara 'black';

sarï 'yellow', cf. Old Turkic sarïg 'yellow'.

${ }^{1}$ Erdal claims that this colour name might be derived from the word qüz 'fervour, ignition'. At first, the verb qizsii- 'to glow' was formed by the denominal verbal suffix $+s X$-, and later it was connected to the deverbal adjective suffix $-X l$. So Erdal reconstructs form *qïzsill. 
The usage of colour names in a secondary meaning is a widespread phenomenon in the Kazakh language. This can be connected to the symbolic interpretation of the colour names. For example, aq ('white') tipifies 'good, guiltlessness, innocence', but in some cases it appears as the sign of mourning. Hence, $a q$ can denote 'fact, truth, reality, milk products'. Colour black qara, apart from 'sinfulness', is the symbol of mourning, moreover has a secondary meaning 'shadow, oil'. The word qüzill 'red' can signify mourning as well, but in several expressions and proverbs it turns up as a metaphor of happiness and richness. The word kök 'blue', besides its secondary meanings 'grass, vegetables, fruit', expresses the hues of green, and for that reason symbolises 'freshness, youth, freedom'. The colour sarï 'yellow' also has an important role in Kazakh culture representing impatiance, expectation and illness, which proves its denotation 'jaundice'. Benevolence can be detected in some expressions involving qoyï 'brown'. In Kazakh, the plant 'maidenhair' is worded by the colour boz related to its external characteristic (Kadaşeva 1996, p. 95; Küçük 2010, pp. 185-190).

The colour ala 'multi-coloured, parti-coloured, spotted' has the most varied application in Kazakh. Originally, it must have expressed variegation with the connotation of 'non-monochrome', but nowadays this phrase is connected to the word teybil ${ }^{2}$. On the basis of symbolism, ala can mark tumble and confusion, but in its secondary medical sense it means 'Iris'.

\section{Colour Names and Their Suffixes}

Due to the typological properties of Kazakh, it could be suspected that the formation of tincture of different colours is effected by suffixes. In the collected corpus, there are only few suffixes which form new tones or intensification.

1. $+\check{s} I l$ : According to Erdal (1991, pp. 98-99), it is attested in Old Turkic as $+s I l$. In general, it denotes intensification, but adding to colour names it creates tinctures. It can be demonstrated with the words aqšil 'whitish' and kökšil 'bluish, navy bluish'. A very interesting form is the word köksil 'hunting eagle, brave', which is probably a borrowing from another Turkic language, because the suffix $+s I l$ does not exist in Kazakh.

2. +GIlt: This suffix signifies colour tones as well, like in the case of bozïilt 'greyish', sargïlt 'beige, muddy' and qüzgïlt 'pink, reddish'. Hypotetically, it can be separated into two suffixes, namely two denominal adjectives: + GIl and $+t$. Umber reddish has the parallel variant qüzgilltïm in Kazakh. Laude-Cirtautas (1961, pp. 50-51) claims that the original form must have been + GiltIm, which

${ }^{2}$ Supposedly, this word is of Turkic origin. It is found in Kirghiz as temgil $\sim$ teygil (Judahin 1965 , pp. 722b; 724b). It might be related to the Old Turkic word tamg $a$ 'brand or a mark of ownership placed on animals' (Clauson 1972, p. 504), which was suffixed by the denominal adjective + GIl. In Kazakh, it was probably borrowed from Kirghiz as *temggil $\sim$ tengil, and it was changed to *teymil by metathesis, and later $-m$ - shifted to $-b$-. 
verifies the qïzgillïm 'reddish' word from the Teleut dialect of Altay Turkic. This version is found in some other Siberian Turkic varieties, too. In this manner, Laude-Cirtatutas divides this suffix into + GIl and + tIm, and later it shortened in Kazakh.

3. +GIl: Similarly, this denominal adjective forms colour tones, such as bozgil 'greyish' and qïzïil 'reddish'. This suffix might verify Laude-Cirtautas' argument. It was used in Old Turkic, too, in the same function (Erdal 1991, pp. 98-99).

There are two other denominal adjectives which can be relevant from the aspect of colour names:

4. $+\check{s} A$ : this suffix has a comparative usage and sometimes forms a new semantic variant. For instance, qïzilša 'beet' lost its original reddish meaning, as the word aq̌̌a can denote 'money' and 'whitish' as well. But in the case of qoïrrša 'brownish', there are no special significations.

5. +DAw: It has a comparative function, too, but a secondary meaning was not formed in the case of this suffix, which is demonstrated by the items qoïrlaw 'brownish', köktew 'bluish' and qïzïldaw 'reddish'.

Besides the suffixes forming tones, two colour names come into view in Kazakh, which are borrowings and considered to be basic colour names in other languages:

1. külgin expresses 'purple, ashen, grey' in Kazakh, which is a derived form of $k \ddot{u l l}$ 'ash'. The denominal adjective suffix + GIn is probably of Turkic origin. It is probably related to the Old Turkic denominal nomen suffix $+G A n$ conjuncted to colour names, like kökän 'plump' (Erdal 1991, pp. 85-86).

In connection with boz and külgin, another colour name has to be mentioned which can signify the hues of the grey colour:

2. sur 'grey' is of unknown origin in Kazakh. It might be connected to Written Mongolian sayaral 'grey as a colour of horse-coat', and it could have been borrowed $^{3}$ as *sagur. Later the intervocalic - $\dot{g}$ - might have been dropped, but it is quite problematic, since in the Turkic languages after the dropping of the intervocalic $-\dot{g}$ - the first vowel regularly lengthens assimilating the second (ĖSTJa 2003, pp. 336-337).

3. The other special loanword which signs a colour name is undoubtedly of Mongolic origin. Kögildir 'navy blue, sky blue' is a reborrowing of the originally Turkic kök 'blue' from Mongolic. In Mongolic, it was suffixed with the denominal adjective $+b t U r /+l t U r$ forming colour tones (Khabtagaeva 2001, pp. 146-147). Having a look at the derived colour names in Kazakh, this is seemingly not a very frequent and productive way for the formation of colour names and tinctures.

\footnotetext{
${ }^{3}$ It might verify the Yakut sur 'grey horse coat', because in Yakut the original Turkic initial $s$ - drops regularly, like Old Turkic sï̈t 'milk' < Yakut $\bar{u} t$ id. and Old Turkic sän 'you' < en id. (Johanson 1998, p. 103). Therefore, it could be a borrowing.
} 


\section{Colour-compounding in Kazakh}

The largest group of the Kazakh colour system is made up of compounds. Because of the large number of the items in this category, it can be divided into several subgroups from the aspect of structural characteristics. In this sense, two subgroups can be distinguished: (1) compounds consisting of solely colour names and (2) compounds containing only one colour name. The former subgroup, i.e. colour-compounds, have a special function, since they might express intensification or colour-tinctures, thus the colour-suffixes can be substituted by these constructions. For instance, the tones of brightness and darkness are formed by the colour names aq 'white' and qara 'black'. In addition, these two colour names can create other colour hues, too, in conjunction with other colour names:

$$
\begin{aligned}
& \text { aq sur 'light grey' < aq 'white' + sur 'grey'; } \\
& \text { qara buril 'dark brown'< qara 'black' + buril 'brown'; } \\
& \text { aq sari 'blonde, fair' < aq 'white' + sari 'yellow'; } \\
& \text { qara torï 'chestnut' < qara 'black' + tori 'bay'. }
\end{aligned}
$$

The fusion of other colour names in Kazakh shows a variegated system. The curiosity of these compounds is that the newly formed colours are sometimes not connected to the original tinctures of the constituents:

qïzill-žasil 'reddish, rusty' < qïzil 'red' + žasïl 'green';

sarï-qoÿ̈r 'tawny'< sari 'yellow' + qoyï 'brown'.

The horse coat colours are a specific part of this subgroup. The cult of the horse has always played a great role in Kazakh culture, therefore many colour tones can be found which are used only for the designation of horse-colour. It is conspicuous that a remarkable part of the horse coat colours is of Mongolic origin in Kazakh. It is proved by the compound ala šubar 'party-coloured', where the second constituent is the borrowing of the Mongolian čooqur 'variegated, dappled' (Lessing 1960, p. 199). Similarly, the Mongolic colour küreng ${ }^{4}$ 'dark brown, maroon, deep violet' (Lessing 1960 , p. 505) can be found in Kazakh in the form kürey. However, besides its original meaning, it designates the tone of grey as well. It creates compounds, like alküren ${ }^{5}$ which designates 'a kind of light greyish horse'.

Another peculiar part of the colour-compounds are the totally reduplicated constructions. Generally, this mode of reduplication expresses intensification, although it is not a frequent phenomenon in colour names. In Kazakh, two items can be highlighted, sur-sur 'very green, pale' and tegbil-teybil 'totally spotted, stained'.

The second subgroup, namely compounds which consist of only one colour name, can be uncountably detected in the Kazakh lexicon. Taking stock semantically of the colour-compounds, this category might be separated into numerous categories:

${ }^{4}$ As a hypothesis, it might be a reborrowing. According to Clauson (1972, p. 761), the Mongolic word is connected to the Old Turkic küzen 'polecat' which was later reborrowed by Kazakh as a colour name.

${ }^{5}$ The first constituent of this compound, al, has several usage, like 'crimson', but in compounds it might express the light tone of a colour, too. 
animal names:

aqtorgay 'whitefly' (Latin Aleyrodida) < aq 'white' + torgay 'sparrow';

kökžal 'grey wolf' (Latin Canis lupus) < kök 'blue' + žal 'mane';

sarïköbelek 'lackey moth' (Latin Malacosoma neustria) < sarï 'yellow' + köbelek 'butterfly';

plant names:

bozqaragan 'Chinese wolfberry' (Latin Lycium barborum) $<$ boz 'grey' $+q a-$ rag்an 'acacia';

kökšegül 'Jacob's ladder' (Latin Polemonium) < kök 'blue' + ̌̌A \{Denominal Adjective\} + gül 'flower';

qaraqulaq 'Ugly Milk-cap' (Latin Lactarius turpis) < qara 'black' + qulaq 'ear';

mineral names:

köktas 'lazurite' < kök 'blue' + tas 'stone';

qaraširik 'mould' < qara 'black' + širik 'putrid, doze';

food names:

qïzïl topïraq 'red soil' < qüz̈̈l 'red' + topïraq 'ground';

$a q$ žügeri 'maize grits' < aq 'white' + žügeri 'corn';

qara kesek et 'fatless meat' < qara 'black' + kesek 'piece' + et 'meat';

disease names:

qüzil baliq 'fish fillet' < qüzill 'red' + balï 'fish';

aq qandiliq 'Leukemia' < aq 'white' + qan 'blood' $+D I$ \{Denominal Nomen\} $+L I K$ \{Denominal Nomen $\}$;

qara šešek 'chickenpox' < qara 'black' + šešek 'smallpox; flower';

sarï awru 'Jaundice' < sarï 'yellow' + awru 'disease';

phenomena of nature:

aq tïmïq 'doldrums' < aq 'white' + tïmïq 'calm';

kökmŭz 'ice crust' < kök 'blue' + mŭz 'ice';

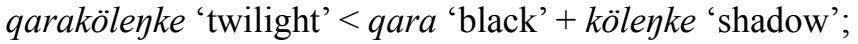

internal human characteristics:

ala köyil 'disingenuous' < ala 'dappled, variegated' + köyil 'spirit, sentiment';

bozbas 'verdant' < boz 'grey' + bas 'head';

qara žürek 'cruel' < qara 'black' + žürek 'heart';

external human characteristics:

aqqŭba 'blond' < aq 'white' + qǔba 'whitish';

qara näsil 'negroid' < qara 'black' + näsil 'race';

kök köz 'blue eye' < kök 'blue' + köz 'eye'.

In this process, almost every Kazakh colour name comes into view. Nevertheless, for a right and obvious semantic classification of colour-compounds, this point of view is not sufficient, because many times the concrete meaning of the compound is not clear. Therefore, the compounds should be classified according to the interpreted meaning of the constituents. As far as it can be interpreted, the compound is regarded as compositional, otherwise as non-compositional (Fabb 1998, p. 6). The question of the compositional compounds has already been demonstrated through former examples. 
As for the non-compositional constructions, they cannot be explained without a deeper knowledge of Kazakh colour names. In most cases, the denotation is related to the symbolic or secondary meaning of the colour name.

The symbolic usage of the colours $a q$ 'white' and qara 'black' is quite abundant in compounds like the image of guiltlessness and sinfullness, and they might have special symbolic interpretations as well, based on the 'external characteristics':

aqpeyil 'sinless, innocuous' < aq 'white' + peyil 'intention';

qarabet 'dishonest, infamous' < qara 'black' + bet 'face';

aq tamaq 'female beauty' < aq 'white' + tamaq 'throat';

qara šä̈̈raq 'homeland, the youngest child in the family' < qara 'black' + šäiraq 'blow-hole at the upper part of the yurt'.

The colour kök 'blue, green' forms compounds representing virility and the vegetation of nature. Moreover, it sometimes appears as the tone of grey or black:

kökbalausa 'fresh, spring grass' < kök 'blue, green' + balausa 'verdant fruit, young';

kökželik 'the shedding of domestic animals in the springs' < kök 'blue, green' $+z ̌ e l i k$ 'abandon, fervour';

$k o ̈ k$ at signifies 'grey horse' < kök 'blue, green' + at 'horse';

kökžiydek is applied to the apellation of 'black currant' (Latin Vaccinia uliginosum) < kök 'blue, green' + žiydek 'fruit'.

In some cases the tinctures of the tawny and white colours are substituted by the word sarï 'yellow':

sargi̋̌s žündi 'reddish, tawny hairy' < sarï 'yellow' + GIš \{Denominal Adjective $\}+$ žün 'hair, fur' $+D I$ \{Denominal Adjective\};

sarïsoyaw 'lactic acid' < sari 'yellow' + soyaw 'thorn, prickle'.

The basic colour name $b o z$ 'grey' is presented as the synonym of youth. In addition, this colour is connected to serenity as well:

bozbalalï 'young, youngster' < boz 'grey' + bala 'child' +LIK \{Denominal Adjective\};

bozökpe 'speechless, calm'< boz 'grey' + ökpe 'lungs'.

Colour brown qojür symbolises coolness in Kazakh:

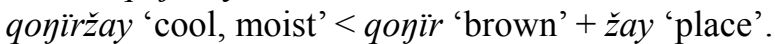

Beside the colours $b o z$ and $k o ̈ k$, grey might also be expressed by ala 'variegated, spotted', and it is used figuratively as calamity and insincerity:

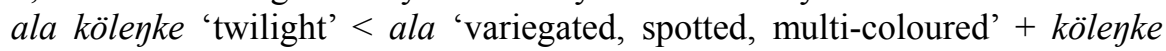
'shadow';

ala topalay 'fear, panic' < ala 'variegated, spotted, multi-coloured' + topalay 'panic, excitement';

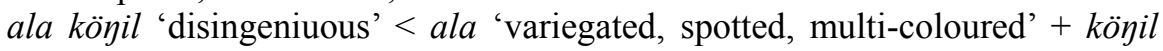
'desire, mind'. 


\section{Conclusion}

Having reviewed the colour names of the Kazakh language, it becomes evident that this system is very diversified and complex. On the basis of Kazakh word formation, there are many ways of creating colour names and tones. It is remarkable that the formation of colour names by making compounds is a frequent process, similarly to suffixation. In addition, the symbolic and secondary meaning of the colour names often come into being only through compounding. So colour-compounding is an important and useful process to gain a deeper insight into the historical and cultural background of the Kazakh language. It would also be important to compare the Kazakh colour names to other Turkic systems.

\section{References}

Balakaev, M. B.-Baskakov, N. A.-Kenesbaev, S. K. (1962): Sovremennyj kazahskij jazyk. Almaty, Akademiia nauk Kazahskij SSR.

Bektaev, K. B. (1999): Ülken kazakša-oryš̌a oryš̌a-kazakša sözdik = Bol'šoj kazahsko-russkij russko-kazahskij slovar'. Almaty, Kazyna.

Berlin, B. - Kay, P. (1968): Basic Colour Terms. London, University of California Press.

Biggam, C. P. - Kay, C. J. (eds) (2006): Progress in Colour Studies. Glasgow, John Benjamins Publishing.

Clauson, G. (1972): An Etymological Dictionary of Pre-thirteenth-century Turkish. Oxford, Clarendon.

Eminoğlu, Hatice (2014): Türkçede Renkler Sözlüğü. Ankara, Gazi Kitabevi.

Erdal, M. (1991): Old Turkic Word Formation. 2 vols. Wiesbaden, Harrassowitz Verlag.

ĖSTJa (2003): Levitskaja, L. S. - Dybo, A. V.-Rassadin, V. I. (eds): Étimologičeskij slovar' tjurkskih jazykov. Obščetjurkskie i mežtjurkskie osnovy na bukvy «l, m, n, p, s». Moskva, Nauka.

Fabb, N. (1998): Compounding. In: Spencer, A.-Zwicky, A. M. (eds): Handbook of Morphology. Oxford, Blackwell, pp. 66-83.

Johanson, L. (1998): The History of Turkic. In: Johanson, L. - Csató, É. Á. (eds): The Turkic Languages. London-New York, Routledge, pp. 81-125.

Judahin, K. K. (1965): Kirgizsko-russkij slovar'. Moskva, Sovetskaja ėnciklopedija.

Kadaşeva, K. (1996): Kazak Medeniyeti'ndeki Semboller. In: Tural, S. - Kılıç, E. (eds): Nevruz ve Renkler. Ankara, Atatürk Kültür Merkezi Yayınları, pp. 95-97.

Kay, P.-McDaniel, C. (1978): The Linguistic Significance of the Meanings of Basic Color Terms. Language Vol. 54, No. 3, pp. 610-646.

Kenesbaev, S. K. (1977): Qazaq tilining frazeologijalyk sözdigi. Almaty, Kazak SSR Gylym akademijasynyn baspasy.

Khabtagaeva, B. (2001): Colour Names and Their Suffixes. A Study on the History of Mongolian Word Formation. $A O H$ Vol. 54, pp. 85-165.

Kirchner, M. (1998): Kazakh and Karakalpak. In: Johanson, L.-Csató É. Á. (eds): The Turkic Languages. London-New York, Routledge, pp. 318-332.

Koç, K. (2003): Kazak Türkçesi Türkiye Türkçesi Sözlüğü. Ankara, Akçağ.

Krippes, K. (1997): Kazakh Grammar with Affix List. Kensington, Dunwoody.

Küçük, S. (2010): Eski Türk Kültüründe Renk Kavramı. Bilgi Vol. 54, pp. 185-210. 
Laude-Cirtautas, I. (1961): Der Gebrauch der Farbbezeichnungen in den Türkdialekten. Wiesbaden, Harrassowitz Verlag.

Lessing, F. (1960): Mongolian-English Dictionary. Berkeley-Los Angeles, University of California Press.

Róna-Tas, A.-Berta, Á. (2011): West Old Turkic. Turkic Loanwords in Hungarian. 2 vols. Wiesbaden, Harrassowitz Verlag.

Sipőcz, K. (1994): A vogul nyelv színnevei [Colour names in Vogul]. Szeged, JATE Press.

Stachowski, M. (2010): Is the Yakut Fox Green? Or Remarks on Some Colour Names in Turkic, Uralic and Yeniseic. In: Górnikiewicz, J.-Grzmil-Tylutki, H.-Piechnik, I. (eds): En quête de sens. Études dédiées à Marcela Światkowska. W poszukiwaniu znaczeń. Studia dedykowane Marceli Świątkowskiej. Kraków, Wydawnictwo Uniwersytetu Jagiellońskiego, pp. $539-548$.

Žanpejisov, E. -Žusajin, A. et al. (eds) (2002): Kazak Grammatikasi. Astana, Astana Poligrafija. 